\title{
Prevalence of Bombay Group Blood in Southern Bengal Population
}

\author{
Biplabendu Talukder $\cdot$ Suvro Sankha Datta $\cdot$ \\ Somnath Mukherjee $\cdot$ Krisnendu Mukherjee
}

Received: 22 June 2013/Accepted: 5 August 2013/Published online: 11 August 2013

(C) Indian Society of Haematology \& Transfusion Medicine 2013

To the Editor,

Bombay blood group ( $\mathrm{h} / \mathrm{h}$ or Oh phenotype) first discovered in Bombay, by Dr. Y.M. Bhende in the year of 1952, now Bombay known as Mumbai in India. Individuals with the rare phenotype (hh) do not express $\mathrm{H}$ antigen (also called $\mathrm{H}$ substances), the antigen which is present in blood group $\mathrm{O}$. A fucose molecule attached via alpha 1-2 linkage with terminal galactose molecule of a tetrasaccharides known as $\mathrm{H}$ antigen. Fucosyltransferase, an enzyme responsible for expression of $\mathrm{H}$ antigen. Fucosyltransferase enzymes encoded by two different genes known as FUT 1 (H gene) and FUT 2 (Se gene).

Homozygosity for defective mutation of both FUT 1 and FUT 2 genes causes lack of $\mathrm{H}(\mathrm{hh})$ antigen and non secretor (se,se) expression. This is known as Bombay phenotype. They are unable to make A antigen or B antigen on their red blood cells, although they may have the $\mathrm{A}, \mathrm{B}$ or $\mathrm{AB}$ blood group genes. Bombay phenotype can donate $\mathrm{RBCs}$ to any member of the $\mathrm{ABO}$ blood group system if the Rhe$\operatorname{sus}(\mathrm{Rh})$ antigens are compatible. They must receive blood from the people who have the Bombay phenotype only.

In the general population the prevalence of Bombay blood group is about 1 in 10,000 individuals in India and 1 per 1,00,000 individuals in Europe [1]. Although in some places of Mumbai (formerly Bombay) the prevalence of this phenotype is as high as $0.01 \%$ prevalent. High incidence of Bombay phenotype reported in Orissa of eastern India, among Kutia Kondh tribe [2]. Another study from northwestern Orissa reported an average of 1 in 278 Bombay phenotype among Bhuyan tribal population [3].

B. Talukder $(\bowtie) \cdot$ S. S. Datta $\cdot$ S. Mukherjee $\cdot$ K. Mukherjee Department of Immunohematology and Blood Transfusion, Medical College Hospital, Kolkata, India e-mail: drbiplabendutalukder@gmail.com
On routine blood grouping of 28,934 blood donors across the southern part of West Bengal, who have donated blood in different blood donation camps organized by the Medical College Hospital, Kolkata, on 2012, we detected two male donors (aged 35 and 40 years) having Bombay (hh) phenotype.

On the other hand Bombay (hh) phenotype was present in 4 out of 27,531 patients, who received blood or blood components from our department in the same year. However the blood bank could supply only two units of Bombay phenotype red cells to 2 of these 4 patients, whom blood was required due to obstetrical emergencies (post partum hemorrhage and acute ruptured ectopic pregnancy).

On the basis of above results we have noted the prevalence of Bombay phenotype in our donors to be $0.007 \%$ (2 of 28,934), and $0.014 \%$ (4 of 27,531) among patient population, with an overall prevalence of $0.011 \%$ (6 out of $56,465)$.

It is very difficult to supply Bombay phenotype RBCs in hospital admitted recipient in emergency situation, therefore maintaining a Bombay phenotype donor registry is of paramount importance in order to save some of these patients.

Conflict of interest None.

\section{References}

1. Oriol R, Canelier JJ, Mollicone R (2000) Molecular genetics of H. Vox Sang 78:105-108

2. Balgir RS (2006) Health and morbidity pattern in the tea garden labour communities of north east India. In: Sarthak S (ed) The tea labourers of north east India. Mittal Publications, New Delhi, pp 223-235

3. Balgir RS (2007) Identification of a rare blood group "Bombay (Oh) phenotype" in Bhuyan tribe of northwestern Orissa, India. Indian J Hum Genet 13:109-113 